\title{
Continent formation in the Archean and chemical evolution of the cratonic lithosphere
}

\author{
R.P. Rapp, G.M. Yaxley, and M.D. Norman \\ Research School of Earth Sciences, Australian National University, Canberra ACT 0200 Australia
}

\begin{abstract}
Despite evidence for the presence of continental crust on Earth at 4.2-4.4 Ga ago (Harrison et al., 2005), no rocks older than $\sim 4.0 \mathrm{Ga}$ survive, and consequently, the question of when and how Earth's first continents formed (as opposed to its earliest granitic crust) remains highly debatable. The physical and temporal juxtaposition of the oldest preserved granitoid rocks with old, cold roots extending deep into the underlying cratonic lithospheric mantle suggests a linked evolutionary history. Understanding the genetic relationship between Archean continental crust and cratonic lithosphere is therefore crucial to understanding how physically and chemically stable continental nuclei (cratons) formed.
\end{abstract}

The vast majority of continental crust of early-mid Archean age ( 3.8-3.0 Ga old) is comprised of TTG (trondhjemite-tonalite-granodiorite) granitoids (Martin et al., 2006). These rocks, believed to be derived by low-moderate degrees of dehydration melting of garnet-bearing metabasalt (garnet amphibolite to eclogite; Rapp and Watson, 1995), closely resemble compositionally so-called "adakite" lavas and related intrusive granitoids found in modern subduction zones. Adakite lavas are relatively rare and generally restricted to convergent plate margins with unusually "hot" subduction geotherms, and are often associated with "juvenile" intra-oceanic arc settings, where subduction of young oceanic lithosphere and actively spreading ridges is involved. Archean TTG and Mesozoic to Cenozoic subduction-related adakites are virtually identical in terms of many key geochemical parameters indicative of dehydration melting of garnetbearing metabasalt (e.g., high $\mathrm{Na}_{2} \mathrm{O} / \mathrm{K}_{2} \mathrm{O}$, high $\mathrm{Al}_{2} \mathrm{O}_{3}$ and $\mathrm{SiO}_{2}$; high $\mathrm{Sr} / \mathrm{Y}$ and $\mathrm{La} / \mathrm{Yb}$ ratios coupled with strongly depleted $\mathrm{Y}$ and $\mathrm{Yb}$; and highly depleted in high-field strength elements, such as $\mathrm{Nb}$, Ta, Zr and Hf relative to elements of similar compatibility; see Munker et al., 2004). Thus it would seem as if adakite magmatism in modern subduction zones would be an appropriate analog for TTG granitod magmatism in the Archean. However, important and significant differences have emerged between TTG and modern adakites with respect to those elements indicative of a mantle lineage; for example, adakites show a broad range of values in terms of their molar ratio of $\mathrm{Mg}$ / $(\mathrm{Mg}+\mathrm{Fe})$, or $M g$-number $(\sim 0.30-0.70)$, whereas TTG possess a more restricted range at lower Mg-number ( 0.30-0.50). Adakites also possess a broader range and higher absolute concentrations of elements such as $\mathrm{Cr}$ and Ni than TTGs (see Fig. 1). These compositional trends, in which a "mantle signature" is superimposed on a "mafic crustal melting signature", can be shown to extend to putative "primitive" (and "primary") arc granitoids, including high-Mg andesites (HMAs: Kelemen ) and bajaites (Calmus et al., 2004; GomezTuena et al., 2007), and reflect a crucial role for the mantle wedge in the petrogenesis of adakite-related arc magmatism.

The compositional continuuum apparent between adakites and primitive HMAs and bajaites reflects variable extents of interaction between primary adakite melts, formed by melting of garnet-bearing mafic crust, and peridotitic lithologies in the mantle wedge. The absence of these "primitive" geochemical signatures in early-mid Archean TTGs suggests that there was little or no mantle involvement in granitoid magmatism prior to $3.0 \mathrm{Ga}$ ago. It is only with the appearance in the Late Archean ( 3.0-2.8 Ga ago) of monzodiorites and trachyandesites of the sanukitoid suite (Shirey and Hanson, 1984) that granitoids with a clear and distinct mantle lineage can first be identified, with the implication that these magmas marks the beginning of "modern-style", plate tectonics subduction (e.g., downgoing slab, overlying mantle wedge, and crustal growth via "the andesite model"; Arculus, 2006). How does this Late Archean transition in granitoid magmatism affect the chemical evolution of cratonic lithosphere? In this study, we focus on the reaction between TTG melts and mantle peridotite in the juvenile root zone of an Archean craton, presenting the results of a variety of laboratory experiments in which $\mathrm{SiO}_{2}$-rich melts are allowed to equilibrate with mantle mineral assemblages.

\section{Experimental approach}

Reaction between silicate melts and peridotite "rock" have been studied in the past using a variety of experimental techniques, including "sandwich" experiments in which a partial melting is induced in a layer of basalt, with the silicate melt migrating into and 
reacting with an adjacent layer of peridotite (e.g.,, Sen and Dunn, 1994; Yaxley and Green, 1998: Rapp et al., 1999). The same equilibrium can also be achieved through "liquidus saturation" experiments similar to those of Wyllie and coworkers (e.g., Johnston and Wyllie, 1989), in which various proportions of silicate "melt" (glass) are mized with peridotite rock powder and allow the to equilibrate at elevated temperature and pressure (e.g.,). We have carried out both types of experiments.

For the liquidus saturation experiments, hydrous glasses (melts) were synthesized from natural rock powders of (1) a typical TTG granitoid from the Brazilian craton (Martin et al., 1994) and (2) a Superior Province sanukitoid (Stern and Hanson, 1991). These melts were then mixed in various proportions with rock powders made from natural depleted peridotite xenoliths from the Kamchatkan sub-arc mantle (Kepezhinskas et al., 1995), sealed in pressure-welded gold capsules. Piston-cylinder and multianvil experiments were conducted between 1.5 and $4.0 \mathrm{GPa}$, over a temperature range from 1100$1300^{\circ} \mathrm{C}$. We also report data for additional "sandwich" experiments using techniques similar to those described by Rapp et al., 1999. The resulting mantlehybridized melts and melt metasomatized peridotite assemblages were analyzed for major and trace elements using the ANU's electron microprobe and laser ablation ICP-MS facilities, respectively.

\section{Results I: Primitive Mg-rich granitoids}

Phase assemblages produced in our experiments consist of mantle-hybridized TTG meklts in equilibrium with modally metasomatized pyroxenitic residues resulting from reactions that form orthopyroxene at the expense of olivine. At pressures below $2.0 \mathrm{GPa}$, reaction residues of amphibole-bearing pyroxenite (opx + cpx) coexist with Mg-rich diorite melts with "primitive", mantle-derived geochemical traits, including elevated $\mathrm{Mg}$-numbers $>0.55$ and significantly higher $\mathrm{Ni}$ and $\mathrm{Cr}$ concentrations (Fig. 1). At higher pressures, reaction residues consist of garnet websterite $(\mathrm{gt}+\mathrm{cpx}+\mathrm{opx})$ with metasomatic phlogopite replacing amphibole, also coexisting with $\mathrm{Mg}$-rich diorite melt. Despite complete equilibration with peridotitic phase assemblages, the distinctive geochemical features of the original TTG melts and the overall shape of their trace element distribution patterns remain intact, but overprinted by a primitive mantle signature. Our results suggest that primitive granitoids possessing a crustal melting signature will form over a broad range of pressure and temperature conditions by reaction between primary TTG melts and mantle peridotite. These liquids, closely resembling Late Archean sanukitoids, fall along a compositional trend that includes primitive, magnesian-rich granitoids found in modern arcs (HMAs and bajaites). Thus primitive $\mathrm{Mg}$-rich granitoids can be directly linked genetically to the formation of orthopyroxene-rich, olivine-depleted, metasomatic pyroxenite assemblages

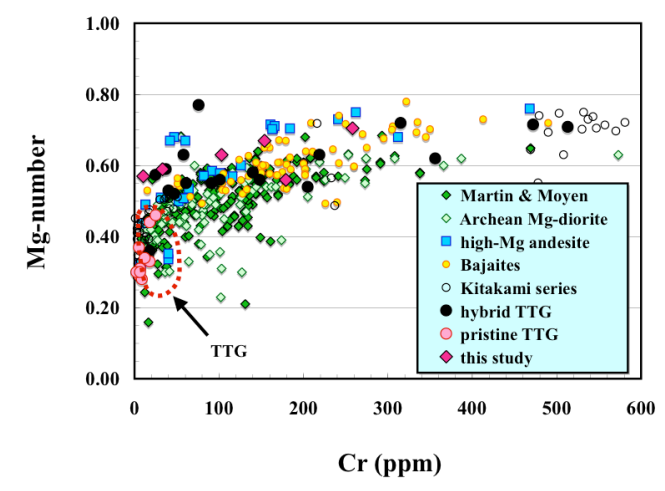

Figure 1. Concentrations of $\mathrm{Cr}$ versus molar $\mathrm{Mg} /(\mathrm{Mg}+\mathrm{Fe})$ for experimental "pristine TTG" and "mantle-hybridized" counterparts, shown relative to late Archean sanukitoids and Mg-rich diorites (H. Martin and J.-F. Moyen, unpublished data), and adakite and "primitive" andesites and bajaites from modern arc environments. Adakites from the Kitakami Mountains in NW Japan range acrosss the full spectrum from relatively pristine, low-Mg number adakites to HMAs (Tsuchiya et al., 2005).

in the lithospheric mantle beneath a thickening Archean magmatic arc.

A consistent picture is now emerging from these experiments, one that accounts for the shift in the locus of granitoid magmatism from crustal, metabasaltic sources in the early-mid Archean to a (hybrid) mantle source in the late Archean, with the geochemical traits of late Archean Mg-rich diorites (sanukitoids) explicable in terms of hybridization of initally "pristine" TTG melts formed by assimilation of peridotite (largely the consumption of olivine), and/or subsequent partial melting of TTG-metasomatized "hybrid" mantle. The interrmediate (between eclogite and peridotite), garnet websterite xenolith parageneses (Aulbach et al., 2002) appear to be the natural equivalents of our melt-rock reaction residues, a conclusion we intend to test by comparing the trace element characteristics of individual phases in our experimental residues, with those in xenoliths of this paragenesis.

\section{Results II: Crystalline reaction residues}

The experiments demonstrate that the crystalline reaction residues formed as a consequence of $\mathrm{SiO}_{2}$-rich melts migrating across the crust-mantle interface are dominated by modal metasomatic orthopyroxene and hydrous minerals such as amphibole and phlogopite, all forming at the expense of olivine. Metasomatic orthopyroxene is enriched in $\mathrm{CaO}$ and $\mathrm{Al}_{2} \mathrm{O}_{3}$ and has lower Mg-numbers than "peridotitic" opx, and $\mathrm{Mg \#}$ decreases and $\mathrm{CaO}$ and $\mathrm{Al}_{2} \mathrm{O}_{3}$ content increases as the proportion of "melt" relative to "rock" increases. Stabilization of hydrous minerals (amphibole and phlogopite) is favored by lower temperatures and lower melt:rock ratios. Garnet in both garnet websterite and elogitic experimental reaction assemblages has an intermediate major element composition comparable to 
garnet of the "websteritic" paragenesis (intermediate to garnet from the eclogitic and peridotitic parageneses).

\section{Results III: Trace element partitioning between high-Mg diorite melts and websteritic reaction residues.}

In addition to measuring a full range of trace elements in the mantle-hybridized high-Mg diorite (sanukitoid and HMA) melts, we have been able to focus the laser ablation beam on numerous crystals of the reaction residues, including amphibole, garnet, orthopyroxene and clinopyroxene. These analyses provide the means for comparison with subcratonic mantle xenoliths of websteritic affinity, in order to assess the evidence for pervasive melt:rock reaction in the lithosphere beneath the granitoids of the cratonic crust. These analyses also provide the necessary data for calculating mineral-melt distribution coefficients that will be useful in geochemical modelling of cratonic lithosphere evolution in the Archean. Our preliminary results clearly show that, garnet-melt trace element D's from the hybrid phase assemblages, for instance, fall entirely within the range of garnet-melt D's measured for eclogitic garnet, and therefore during interaction between TTG melts and garnet peridotite, garnet in the reaction residue will not alter appreciably the disitnctive trace element characteristics of TTG (and adakite) liquids. This is in fact what is observed whenn late Archean sanukitoids are compared with early-mid Archean TTGs, or when adakites in modern arcs are compared with Hmas and bajaites.

\section{Summary}

Increasingly intimate and extensive interaction between silica-rich, hydrous TTG melts and mantle peridotite (e.g., Kelemen et al., 1998) in the Late Archean may be the dominant process governing both granitoid magmatism in the thickening primitive "arc" (the continental nuclei) and chemical maturation of its subarc roots in the underlying mantle (i.e., the evolving cratonic lithosphere). Just as TTG may be paired with eclogite residues in the cratonic lithosphere as possible melt-residue pairs, so too might late Archean sanukitoids be paired with websteritic (pyroxenitic) reactuion residues formed by melt-rock reaction. Late Archean primitive granitoids of the sanukitoid suite may mark the point at which the mantle first begins to participate in the growth of the continental crust.

\section{References}

Arculus, R. (2006) The andesite model of continental crust origins. Geochimica Cosmochimica Acta 70, 18 Supplement 1, A20.

Aulbach, S., Stachel, T., Viljoen, K.S., Brey, G.P., Harris, J.W. (2002) Eclogitic and websteritic diamond sources beneath the Limpopo Belt- is slab melting the link? Contributions to Mineralogy and Petrology 142, 56-70.

Calmus, T., Aguillon-Robles, A., Maury, A.C., Bellon, H., Benoit, M. Cotton, J., Bourgois, J., Michaud, F., 2003. Spatial and temporal evolution of basalts and magnesian andesites ("bajaites') from Baja California, Mexico: the role of slab melts. Lithos 66, 77-105.

Gomez-Tuena, A., Langmuir, C.H., Goldstein, S.L., Straub, S.M., Ortega-Gutierrez, F., 2007. Geochemical Evidence for Slab Melting in the Trans-MexicanVolcanic Belt. Joural of Petrology 48, 537-562.

Harrison,, T.M., Blichert-Toft, J., Muller, W., Albarede, F., Holden, P., Mojzsis, S.J. (2005) Heterogeneous Hadean Hafnium: evidence of continental crust at 4.4 to $4.5 \mathrm{Ga}$. Science 310, 1947-1950.

Johnston, A.D., Wyllie, P.J., 1989. The system tonaliteperidotite- $\mathrm{H} 20$ at $30 \mathrm{kbar}$, with applications to hybridization in subduction zone magmatism. Contributions to Mineralogy and Petrology 102, 257-264.

Kelemen, P.D., Hart, S.R., Bernstein, S., 1998. Silica enrichment in the continental upper mantle via melt/rock reaction. Earth and Planetary Science Letters 164, 387406.

Kelemen, P.B., Hanghoj, K., Greene, A.R., 2003. In: The Crust (ed. R.L. Rudnick) Vol. 3 Treatise on Geochemistry (eds. H.D. Holland and K.K. Turekian). Elsevier-Pergamon, Oxford.

Kepezhinskas, P., Defant, M.J., Drummond, M.S., 1996. Progressive enrichment of island arc mantle by meltperidotite interaction inferred from Kamchatka xenoliths. Geochimica Cosmochimica Acta 60, 1217-1229.

Munker, C., Worner, G., Yogodzinski, G., Churikova, T., 2004. Behaviour of high field strength elements in subduction zones: constraints from Kamchatka-Aleutian arc lavas. Earth and Planetary Science Letters 224, 275293.

Martin, H., Peucat, J.J., Sabate, P., Cunha, J.C., 1997. Crustal evolution in the early Archena of South America: example of the Sete Voltas Massif, Bahia State, Brazil. Precambrian Research 82, 35-62.

Martin, H., Smithies, H., Rapp, R.P., Champion, D., Moyen, J.F., 2005. An overview of the TTG/adakite/sanuki-toid relationship and implications for continental crust genesis and evolution. Special Issue on "Geodynamic controls on adakite, TTG and sanukitoid genesis: implications for models of crust formation", H. Rollinson, H. Martin, and M. Polve (Eds.) Lithos, 79, 1-24.

Rapp, R.P., Shimizu, N., Norman, M.D., Applegate, G.S., 1999. Reaction between slab-derived melts and peridotite in the mantle wedge: experimental constraints at $3.8 \mathrm{GPa}$. Chemical Geology 160, 335-356.

Rapp, R.P., Watson, E.B., 1995. Dehydration melting of metabasalt at 8-32 kbar: Implications for continental growth and crust-mantle recycling, Journal of Petrology 36, 891-931.

Sen, C., Dunn, T., 1994. Experimental modal metasomatism of a spinel lherzolite and the production of amphibolebearing peridotite. Contributions to Mineralogy and Petrology 119: 422-432.

Shirey, S.B., Hanson, G.N., 1984. Mantle-derived Archeaen monzodiorites and trachyandesites. Nature 310, 222-224.

Stern, R.A., Hanson, G.N., 1991. Archean high-Mg granodiorite: a derivative of light rare-earth enriched monzodiorite of mantle origin. Journal of Petrology 32, 201-238.

Tsuchiya, N., Suzuki, S., Kimura, J-I. and H. Kagami (2005) Evidence for slab melt/mantle reaction: petrogenesis of Early Cretaceous and Eocene high-Mg andesites from the Kitakami Mountains, Japan. Lithos 79, 179-206.

Yaxley, G.M., Green, D.H., 1998. Reactions between eclogite and peridotite: mantle refertilisation by subduction of oceanic crust. Schweizer Mineralogisc Petrographic Mittern 78, 243-255. 